\title{
OPTIMALISASI LAHAN PEKARANGAN UNTUK PEMENUHAN PAKAN USAHA TERNAK DOMBA SKALA RUMAH TANGGA
}

\author{
Sri Nastiti Jarmani dan Sajimin \\ Balai Penelitian Ternak \\ Email: srinastitijarmani@yahoo.com
}

\begin{abstract}
ABSTRAK
Masyarakat di pedesaan telah mengenal budidaya ternak ruminansia sejak puluhan tahun lalu, namun hingga saat ini cara membudidayakannya masih seperti para pendahulunya yaitu tradisional, usaha sambilan, sebagai tabungan atau status sosial. Domba merupakan ternak yang sangat populer untuk dipelihara karena mudah pemeliharaannya, modal relatif lebih rendah dibanding sapi dan mudah untuk dijual. Hasil pengamatan di Kabupaten Brebes, Kabupaten Blora dan Kabupaten Indramayu menunjukkan bahwa rumput lapang adalah jenis pakan hijauan yang biasa diberikan selain rumput "kalanjana" yang tidak dibudidaya, belum ada gerakan penghijauan pekarangan dan lahan diantara tanaman utama dengan tanaman pakan ternak yang berfungsi banyak. Terdapat kecenderungan produktivitas domba rendah dan sulit untuk mendapatkan domba dengan bobot lebih dari $40 \mathrm{~kg}$. Kekurangan pakan, manajemen perkawinan yang tidak terkontrol, pemasaran dan pemotongan domba betina dibawah umur lima bulan merupakan sebagian faktor penyebabnya. Program penghijauan dengan tanaman pakan jenis leguminosa berfungsi banyak seperti Sesbania grandiflora, Leucaena, Gliricidia (turi, lamtoro, gamal) serta leguminosa herba Clitoria ternatea (kembang telang) diantara tanaman pokok (jagung, sayuran) di ladang dan pekarangan secara intensif dan optimal diharapkan dapat meningkatkan produksi hijauan, meningkatkan kualitas pakan, menambah kesuburan lahan dan pada akhirnya dapat memenuhi kebutuhan gizi domba. Perbaikan manajemen dan pengawalan teknologi menuju budidaya domba yang baik dan benar (good farming management) sangat diperlukan untuk meningkatkan produktivitas dan meningkatkan pendapatan masyarakat peternak domba skala rumah tangga. Selanjutnya pemenuhan kebutuhan pakan disertai dengan perbaikan manajemen perkawinan yang terarah dapat mencegah terjadinya perkawinan inbreeding yang pada akhirnya akan meningkatkan produktivitas domba dan menambah pendapatan keluarga peternak.
\end{abstract}

Kata kunci : optimalisasi, pakan, lahan, domba.

\section{PENDAHULUAN}

Populasi domba di Indonesia hampir mencapai 10,5 juta ekor di tahun 2013 (Ditjen PKH. 2013) yang sebagian besar dibudidayakan masyarakat di pedesaan di Pulau Jawa dengan cara tradisional, digembalakan di lahan sawah setelah panen, kawasan perkebunan dan lapangan, seperti yang dilakukan oleh para pendahulunya meski ada beberapa daerah yang memelihara secara intensif dimana pakannya disajikan yang terdiri dari rumput lapangan, dedaunan dan sisa panen tanaman sayuran. Tanaman pakan ternak tidak dibudidaya oleh masyarakat karena bukan tanaman utama yang dapat dikuonsumsi dan menambah pendapatan.

Keterbatasan tanaga kerja, kekurangan pakan, sistem perkawinan yang tidak terarah dan banyaknya pemotongan anak domba betina dibawah umur lima (5) bulan menjadi bagian dari penyebab rendahnya jumlah kepemilikan domba dan produktivitas rendah. Padahal dengan memelihara domba kesulitan ekonomi dalam keluarga yang bersifat mendadak dapat teratasi karena domba mudah dijual dibandingkan dengan sapi. Devendra (1993) menambahkan bahwa domba merupakan salah satu penyumbang total pendapatan bagi keluarga.

Domba di Indonesia termasuk dalam kategori domba prolifik dan mempunyai kemampuan bereproduksi sepanjang tahun (Bradford, 1993) namun daya hidupnya rendah karena produksi susunya sedikit (Bradford dan Inounu. 1996). Rendahnya daya hidup kemungkinan karena pakan yang dikonsumsi terbatas jumlah dan kualitasnya. Peningkatan kualitas dan kuantitas pakan dapat diatasi dengan penanaman dan sosialisasi aneka jenis tanaman pakan ternak dan manfaatnya karena masih banyak masyarakat yang belum tahu. Penanaman tanaman leguminosa pohon (turi, lamtoro, gamal) dan leguminosa herba (Centrosema pubescens) dan rumput gajah pada lahan pekarangan, ladang diantara tanaman utama atau galengan secara optimal dapat meningkatkan produksi hijauan sehingga kebutuhan pakan terpenuhi secara kalitas dan kuantitas, menyuburkan lahan dan ada yang dapat dikonsumsi masyarakat (turi dan lamtoro) 
sehingga akan menambah pendapatan peternak. Dampak dari kecukupan pakan dapat meningkatkan produktivitas domba sehingga disarankan agar secara bersamaan dilakukan pencegahan "pemasaran dan pemotongan domba betina dibawah umur lima bulan" karena tingginya permintaan konsumen terhadap domba betina muda umur dibawah 5 bulan harganya relatif jauh lebih murah dari anak domba jantan sehingga dikawatirkan akan terjadi pengikisan pengganti induk.

\section{METODE PENELITIAN}

Tulisan ini merupakan hasil rangkuman dan pengamatan budidaya domba di peternak rakyat di desa Pandansari Kecamatan Paguyangan Kabupaten Brebes dari tahun 2010 hingga 2013, desa Jomblang Kecamatan Cepu dan desa Jepon Kecamatan Randublatung di Kabupaten Blora dari tahun 2007 hingga tahun 2011 dan desa Jambak Kecamatan Cikedung tahun 2002-2004 dan desa Kalensari di Kabupaten Indramayu tahun 2015 (sedang berjalan). Informasi mendalam untuk megetahui manajemen budidaya dilakukan melalui wawancara dengan ketua kelompok, petugas lapang dan pedagang/blantik domba di pasar hewan dan pedagang/warung sate "domba". Hasil wawancara di telisik kembali (cross check) dengan pengamatan secara langsung tatacara pemeliharaan domba di peternak terutama dalam pemberian pakan dan pengadaannya, pemeliharaan dan pemasaran. Gerakan penghijauan dengan penanaman tanaman pakan ternak berfungsi banyak dan rumput budidaya di lahan pekarangan, ladang dan galengan secara optimal diharapkan dapat membantu memenuhi kecukupan pakan secara kuantitas dan kualitas. Data disajikan secara deskriptif.

\section{Budidaya Tanaman Pakan Ternak}

Ketersediaan pakan untuk domba di peternak rakyat perlu diusahakan agar keberlanjutan usahanya dapat terjaga. Budidaya tanaman pakan jenis leguminosa sebagai sumber hijauan mempunyai beberapa keuntungan yaitu dapat menyediakan protein yang cukup tinggi, murah, mudah didapat dan tersedia sepanjang tahun selain itu tanaman legume sangat baik beradaptasi pada berbagai jenis lahan dan banyak manfaatnya sehingga dikenal sebagai jenis pohon serba guna (JPSG). Penanaman legume pohon seperti Leucaena (Lamtoro), Gliricidia (Gamal), Sesbania grandiflora (Turi) dan legume herba Clitoria ternatea (Kembang Telang) di pekarangan, ladang diantara tanaman utama, galengan selain dapat meningkatkan kesuburan lahan juga dapat meningkatkan produksi hijauan dibandingkan dengan penanaman monokultur tanaman pangan (Sajimin.
1999). ) Ketiga jenis tanaman tersebut mudah ditanam di segala jenis tanah, dapat digunakan sebagai pagar di pekarangan, pembatas pemilikan lahan dan juga dapat digunakan sebagai pakan domba. Jarak tanam di antara tanaman pokok dan di tegalan $50 \times 100$ $\mathrm{cm}$ memanjang sedangkan jarak $25 \times 50 \mathrm{~cm}$ bila untuk pagar. Selain itu bunga turi dan buah lamtoro juga dapat dikonsumsi. Sedangkan kembang telang bunganya berwarna ungu bagus untuk tanaman hias dan juga dapat digunakan sebagai pewarna makanan. Budidaya kembang telang di lahan kering kawasan hutan jati di desa Jomblang Kabupaten Blora tumbuh dengan baik dan produksinya mencapai 0,17 ton/ha/ panen pada panen umur 75 hari (Jarmani et al. 2013) demikian pula dengan pertumbuhan percabangan turi dan lamtoro di kawasan hutan jati cukup berkembang pada musim kemarau panjang. Dalam penerapannya Wina (1992) melaporkan bahwa pemberian daun Gamal dan Lamtoro untuk pakan domba dalam bentuk segar hingga 30\% tidak menimbulkan efek negatif pada pertumbuhan domba. Gerakan penghijauan lahan pekarangan secara lebih optimal dengan tanaman pakan ternak jenis leguminosa sangat diharapkan terutama untuk daerah-daerah padat ternak ruminansia karena kurangnya ketersediaan pakan merupakan masalah utama dalam meningkatkan produktivitas ternak. Dampak dari kecukupan pakan dapat meningkatkan produktivitas domba sehingga disarankan agar secara bersamaan dilakukan pencegahan pemasaran dan pemotongan domba betina dibawah umur lima bulan karena dikawatirkan akan terjadi pengikisan domba pengganti induk.

\section{Budidaya Tanaman Pakan Ternak}

Ketersediaan pakan untuk domba di peternak rakyat perlu diusahakan agar keberlanjutan usahanya dapat terjaga. Budidaya tanaman pakan jenis leguminosa sebagai sumber hijauan mempunyai beberapa keuntungan yaitu dapat menyediakan protein yang cukup tinggi, murah, mudah didapat dan tersedia sepanjang tahun selain itu tanaman legume sangat baik beradaptasi pada berbagai jenis lahan dan banyak manfaatnya sehingga dikenal sebagai jenis pohon serba guna (JPSG). Penanaman legume pohon seperti Leucaena (Lamtoro), Gliricidia (Gamal), Sesbania grandiflora (Turi) dan legume herba Clitoria ternatea (Kembang Telang) di pekarangan, ladang diantara tanaman utama, galengan selain dapat meningkatkan kesuburan lahan juga dapat meningkatkan produksi hijauan dibandingkan dengan penanaman monokultur tanaman pangan (Sajimin. 1999). ) Ketiga jenis tanaman tersebut mudah ditanam di segala jenis tanah, dapat digunakan sebagai pagar di pekarangan, pembatas pemilikan lahan dan juga dapat digunakan sebagai pakan domba. 
Jarak tanam di antara tanaman pokok dan di tegalan $50 \times 100 \mathrm{~cm}$ memanjang sedangkan jarak $25 \times 50 \mathrm{~cm}$ bila untuk pagar. Selain itu bunga turi dan buah lamtoro juga dapat dikonsumsi. Sedangkan kembang telang bunganya berwarna ungu bagus untuk tanaman hias dan juga dapat digunakan sebagai pewarna makanan. Budidaya kembang telang di lahan kering kawasan hutan jati di desa Jomblang Kabupaten Blora tumbuh dengan baik dan produksinya mencapai 0,17 ton/ha/ panen pada panen umur 75 hari (Jarmani et al., 2013) demikian pula dengan pertumbuhan percabangan turi dan lamtoro di kawasan hutan jati cukup berkembang pada musim kemarau panjang. Dalam penerapannya Wina (1992) melaporkan bahwa pemberian daun Gamal dan Lamtoro untuk pakan domba dalam bentuk segar hingga 30\% tidak menimbulkan efek negatif pada pertumbuhan domba. Gerakan penghijauan lahan pekarangan secara lebih optimal dengan tanaman pakan ternak jenis leguminosa sangat diharapkan terutama untuk daerah-daerah padat ternak ruminansia karena kurangnya ketersediaan pakan merupakan masalah utama dalam meningkatkan produktivitas ternak. Dampak dari kecukupan pakan dapat meningkatkan produktivitas domba sehingga disarankan agar secara bersamaan dilakukan pencegahan pemasaran dan pemotongan domba betina dibawah umur lima bulan karena dikawatirkan akan terjadi pengikisan domba pengganti induk.

\section{Budidaya Domba}

\begin{tabular}{|c|c|c|c|}
\hline Parameter & Kab. Blora & Kab. Brebes & Kab. Indramayu \\
\hline Pemeliharaan & Intensif & Intensif & $\begin{array}{l}\text { Ekstensif dan } \\
\text { Intensif }\end{array}$ \\
\hline \multicolumn{4}{|l|}{ Pakan: } \\
\hline Jenis Pakan & $\begin{array}{l}\text { R. lapang, daun } \\
\text { nagka, lamtoro } \\
\text { Disajikan }\end{array}$ & $\begin{array}{l}\text { R.lapang, } \\
\text { dedaunan sejenis } \\
\text { legume, sisa } \\
\text { sayuran yang } \\
\text { tidak dijual, daun } \\
\text { wortel air minum } \\
\text { dan garam kadang } \\
\text { diberikan }\end{array}$ & $\begin{array}{l}\text { R.lapang, dedak, } \\
\text { garam }\end{array}$ \\
\hline Sumber & $\begin{array}{l}\text { Hutan jati, } \\
\text { sawah, galengan, }\end{array}$ & $\begin{array}{l}\text { Hutan pinus, } \\
\text { kebun, tegalan, } \\
\text { garam beli di } \\
\text { pasar }\end{array}$ & $\begin{array}{l}\text { Perkebunan tebu, } \\
\text { sawah, tegalan, } \\
\text { Dedak dan garam } \\
\text { membeli di pasar }\end{array}$ \\
\hline Penyajian & Di Kandang & Di Kandang & $\begin{array}{l}\text { Dedak, garam, air } \\
\text { saat digembalakan } \\
\text { dan setelah kem- } \\
\text { bali kekandang }\end{array}$ \\
\hline Jumlah Perhari & $\begin{array}{l}1 \text { keranjang } \\
\text { untuk semua } \\
\text { domba }(8-10 \mathrm{~kg})\end{array}$ & $\begin{array}{l}2 \text { - } 4 \text { karung } \\
\text { untuk semua } \\
\text { domba }(30-60 \\
\mathrm{kg})\end{array}$ & $\begin{array}{l}\text { dedak } 1,0-1,5 \\
\mathrm{~kg} \text {; garam 0,50- } \\
\text { 1,0 kg; air 5- } 10 \\
\text { Iter untuk semua } \\
\text { domba }\end{array}$ \\
\hline Kandang & $\begin{array}{l}\text { Lantai tanah, di } \\
\text { dalam rumah dan } \\
\text { atau di dapur }\end{array}$ & $\begin{array}{l}\text { Panggung, tertu- } \\
\text { tup berkelompok, } \\
\text { di perkebunan } \\
\text { teh }\end{array}$ & $\begin{array}{l}\text { Panggung, ber- } \\
\text { pindah - pindah, } \\
\text { mendekati sum- } \\
\text { ber pakan }\end{array}$ \\
\hline $\begin{array}{l}\text { Penanaman } \\
\text { Tanaman } \\
\text { Pakan Ternak }\end{array}$ & Tidak ada & Tidak ada & Tidak ada \\
\hline
\end{tabular}

Dari Tabel 1 rumput merupakan pakan utama dan bila dicermati pakan di desa Pandansari lebih bervariasi(sekitar 16 jenis tanaman) dibanding lokasi lain. Hasil analisa dari laboratorium pakan di Balai Penelitian Ternak kandungan proteinnya 16\% - 18\% kemungkinan karena banyak dedaunannya sejenis leguminosa. Tidak adanya budidaya tanaman pakan ternak di tiga lokasi pengamatan karena domba adalah usaha sampingan dan dengan pakan "seadanya" tetap dapat berproduksi. Terbatasnya ketersediaan pakan dimusim kemarau dan larangan menggembala dan merumput di kawasan kehutanan dan perkebunan berdampak pada kurangnya pakan, selain itu menurut Setiadi et al. (2009) waktu untuk mencari pakan akan lebih lama pada musim kemarau (3-4 jam) dibandingkan dari musim hujan (1-2 jam) untuk sekali perjalanan.Oleh karena itu perlu gerakan penghijauan lahan pekarangan, ladang dan galengan dengan tanaman pakan jenis leguminosa pohon dan leguminosa herba serta rumput unggul dengan pendekatan "learning by doing" (belajar sambil melaksanakan) agar kebutuhan pakan tercukupi.

\section{KESIMPULAN DAN SARAN}

Budidaya domba di peternak rakyat perlu terus dijaga keberadaannya dengan memperbaiki tatacara pengadaan dan penyediaan hijauan pakan yang berkualitas untuk meningkatkan produktivitas ternak dan pendapatan peternak.

Gerakan penghijauan dengan mengoptimalkan lahan pekarangan, ladang dan galengan dengan tanaman pakan ternak bergizi dan berproduksi tinggi seperti lamtoro, turi, gamal, kembang telang dan rumput gajah dapat mencukupi ketersediaan kebutuhan pakan hijauan sepanjang tahun sehingga dapat meningkatkan produktivitas

Peningkatan produktivitas perlu dibarengi dengan peningkatan pengawasan penjualan dan pemotongan domba betina dibawah umur lima bulan untuk mencegah pengikisan calon betina pengganti induk

\section{DAFTAR PUSTAKA}

Bambang Setiadi, Subandriyo, S.N.Jarmani, D. Lubis dan Hastono. 2009. Open Nucleus Breeding System Domba Komposit Resisten Nematoda, Adaptif Pakan Pedesaan di Jawa Tengah dan Banten. Laporan hasil penelitian. Balitnak. Puslitbang Peternakan. Badan Litbang Pertanian.

Bradford,G.E. 1993. Small Ruminant Breeding Strategy for Indonesia. In. Subandryo and Gatenby,R.M.(Eds). Advances in Small Ruminant Research In Indonesia. SR-SRCP, Central Research Institute for Animal Science. Bogor. 
Indonesia.pp.88-94

Bradford,G.E and I.Inounu.1996. Prolific Breeds in Indonesia. In. M.H.Faling (ed). Prolific Sheeps. CAB. International. Oxon,U.K.p 137 - 145

Devendra,C. 1993. Kambing dan Domba di Asia. Dalam Proceeding Kambing dan Domba Di Indonesia. Editor M.W.Tawonszenka, I.M. Mastika, A.Djajanegara, S.Gardiner, dan T.R. Wiradarya. Sebelas Maret University Press. Surakarta.

Direktorat Jenderal Peternakan dan Kesehatan Hewan. 2013. Statistik Peternakan. Direktorat Jenderal Peternakan dan Kesehatan Hewan. Jakarta.

Jarmani, S.N., Sajimin dan A. Anggraeni. 2013. Integrasi Budidaya Sapi di Kawasan Hutan Jati. Laporan Pengawalan Teknologi. Balai Penelitian Ternak.
Sajimin, B.R.Prawiradiputra dan M.Panjaitan. 1999. Integrasi tanaman pakan pada usahatani di Kecamatan Bayongbong. Garut. JITV Vol 4(4). Puslitbangnak. Bogor.p 251-256, E. 1992. Nilai gizi kaliandra, gamal dan lamtoro sebagai suplemen untuk domba yang diberi pakan rumput gajah. Prosiding Pengolahan Hasil dan Komunikasi Hasil-Hasil Penelitian "Teknologi Pakan dan Tanaman Pakan”. Balai Penelitian Ternak. Pusat Wina Penelitian dan Pengembangan Peternakan. Hal 13-20

Wina, E. 1992. Nilai gizi kaliandra, gamal dan lamtoro sebagai suplemen untuk domba yang diberi pakan rumput gajah. Prosiding Pengolahan Hasil dan Komunikasi Hasil-Hasil Penelitian “Teknologi Pakan dan Tanaman Pakan". Balai Penelitian Ternak. Pusat Wina Penelitian dan Pengembangan Peternakan. Hal 13-20 